\title{
Estados em vias de integração e de desintegração
}

JUAN J. LINZ

- ALFRED STEPAN

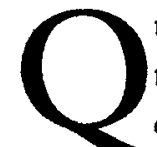

uando refletimos sobre transiçōes para a democracia, nossa tendência é supor que o que se contesta é o regime năo-democrático e que com a democracia se estabelece um novo sistema legítimo. Contudo, em muitos países a crise do regime náo-democrático está misturada com profundas diferenças a respeito do que em verdade constituiria o Estado. Alguns ativistas políticos desafiam simultaneamente o regime antigo, não-democrático, e o próprio Estado territorial existente. Pode-se falar na existência de um problema de estaticidade* quando uma significativa proporção da populaçáo não aceita os limites do Estado territorial (democraticamente constituído ou não) como uma unidade política legítima, à qual deva obediência.

A nova literatura sobre transiçōes democráticas não cogitou e nem deu muita atenção a este problema de estaticidade porque na sua maior parte ocupou-se das transições no sul da Europa e na América Latina, onde o desafio de nacionalismos rivais no interior do território do Estado não era, em verdade, uma questáo destacada (1). Até mesmo os nacionalismos rivais, cataláo e basco, mal entraram na literatura teórica, possivelmente por ter sido conduzida com razoável sucesso a legitimidade da estaticidade da Espanha.

É de se lamentar a omissáo na literatura da questão de legitimidade do Estado, pois esta variável, se bem que nem sempre de grande importância para governos não-democráticos, tem fundamental importância, teórica e política, para a democracia (2).

De fato, acordos sobre estaticidade precedem acordos sobre democracia. Tais acordos năo são necessariamente precedentes para um sistema nāo-democrático. Um sistema não-democrático pode ser capaz de impor aquiescência sobre vastos grupos de população, por longo período de tempo, sem ameaças para a coesão do Estado. Num sistema 
nāo-democrático, o fato da autoridade central não provir nem se manter por competição eleitoral livre significa que as aspiraçóes separatistas ou irredentistas, se existem, não costumam ser invocadas no curso normal da política e podem ser suprimidas. Em nítido contraste, a própria definição de uma democracia envolve a concordância entre os cidadáos de um território, náo importa como especificado, sobre os procedimentos para gerar um governo capaz de fazer exigências legítimas de obediência. Portanto, se um grupo significativo da população năo aceitar como legítimas as reivindicaçóes à sua obediência, por náo querer participar de tal unidade política, não importa como constituída ou reconstituida, isso representará um sério problema para a transição democrática e problemas ainda mais sérios para a consolidação democrática (3).

O grau segundo o qual os habitantes aceitam o domínio e extensão de uma determinada unidade territorial como entidade adequada a tomar decisóes legítimas sobre sua possível futura reestruturaçăo é, assim, uma variável-chave para a teoria democrática. A hipótese daí derivada é portanto: quanto maior a percentagem de povo, em um dado território, que não se sentir membro dessa unidade territorial, não importa como reconstituída, tanto maior será a dificuldade para consolidar uma única democracia dentro dessa unidade.

Note-se que não consideramos serem tais sentimentos acerca da conveniência territorial imutáveis. Acreditamos, ao contrário, que tais sentimentos sejam, em significativa proporçáo, construídos social e politicamente. Elementos do próprio processo, social e político, tais como a maneira como sejam, ou náo sejam, tratados os temores das minorias, podem ser cruciais. Realmente é nossa tese que a sequiência de eleiçóes, per se, pode ajudar a construir identidades, ou a dissolvê-las. Por exemplo, em entes políticos** de multinacionalidades, se primeiro se fizerem eleiçōes nacionais***, haverá fortes incentivos para os ativistas políticos criarem partidos da Uniấo, e uma agenda da Uniăo. Os ganhadores de tais eleiçóes nacionais terão intensificado a legitimidade da União, ou pelo menos teráo acentuado sua legitimidade como um corpo capaz de tomar decisóes compulsórias acerca do futuro da Uniāo. Em contraste, se nesses países de multinacionalidades as primeiras eleições forem regionais, acreditamos que haverá fortes incentivos para a contestação política ficar centrada em questóes étnicas anti-Estado, e que já no dia seguinte às eleições regionais estará mais enfraquecida a legitimidade do Estado.

Também não acreditamos que a teoria democrática deva, implícita ou explicitamente, ter compromisso fechado com a grandeza territorial 
ou integridade territorial em si mesmas. A teoria democrática e a prática democrática precisam ter algum espaço para a secessáo negociada pacíficamente. $O$ problema que estudamos aqui é: quais são as possibilidades de uma determinada unidade territorial conseguir construir uma única democracia consolidada dentro dessa unidade, e se năo conseguir, quais as possibilidades de uma secessão negociada ser pacífica e não complicar ainda mais a construção de democracias nos estados sucessores?

Embora estudemos o tema da estaticidade com muito mais detathes em outro lugar, neste breve ensaio vamos apenas explorar como a seqüência de eleiçóes em si mesma pode desempenhar função importante ao transformar identidades e ao ajudar a integraçáo ou desintegraçáo de estados, especialmente em países multinacionais ou multiculturais altamente heterogêneos (4).

\section{Democratização, eleiçôes gerais e política de integração do Estado: Espanha}

Atualmente está ficando de bom-tom considerar a consolidaçáo espanhola como sendo quase sobredeterminada, devido ao suporte de seu contexto socioeconômico e geopolítico. Acreditamos que uma opinião dessas, sem exame, não somente conduz a uma errônea interpretaçáo do verdadeiro processo de consolidação democrática na Espanha, como também contribui para uma perigosa falta de atenção teórica às relaçóes entre transição democrática, estaticidade e seqüência eleitoral. A Espanha começou o processo de democratização com o potencial de um perigoso problema quanto à sua estaticidade. $O$ mais importante indicador deste perigo está em que, enquanto nem um só oficial de exército foi morto quer na insurgência basca em 1968/75 sob Franćo, quer no período $1975 / 77$ de transiçáo, já no período pós-eleitoral de regime democrático, entre 1978 e 1983, 37 oficiais do exército morreram em conseqüência da violência nacionalista basca (5).

Surpreendentemente, apesar da morte de oficiais militares e das inevitáveis dificuldades em se criar na Espanha um Estado quase-federal, nenhum dos grupos de interesse ou partidos importantes de abrangência nacional alçou-se a responsabilizar o sistema. A adversidade não foi usada deliberadamente seja para deslegitimar o inexperiente regime democrático, seja para fazer oposiçáo às novas estruturas constitucionais, divergentes da tradicional organização do Estado unitário na Espanha. Em nossa opinıáo, a razáo principal dessa falta de acusaçáo ao sistema foi a realização das eleiçóes gerais na Espanha.

Eleiçốes, especialmente eleifóes fundadoras, ajudam a criar agendas, 
atores, organizaçóes e, mais importante ainda, legitimidade e poder. Um dos nossos mais fortes argumentos é que, se um país tem problema da estaticidade, o fato de serem as primeiras eleiçóes nacionais ou regionais faz uma diferença crítica. Na Espanha, as primeiras eleiçóes foram nacionais. Acreditamos que elas ajudaram a transcender o problema da estaticidade naquele país. A primeira votação pós-Franco foi um referendum para aprovar uma "lei para reforma política", lei essa que passou com aprovação de $94,2 \%$ (6). E comprometeu o governo não em detalhes de reforma política, mas num processo de clara democratizafão, $\mathrm{e}$ não de mera liberalizafão(7).

A segunda votação-chave, em 15 de junho de 1977 , também não foi simplesmente sobre liberalização, mas sobre democratização; foi uma eleição nacional, para selecionar os deputados que criariam um governo e redigiriam a nova constituição. Por causa dos interesses nacionais envolvidos, quatro partidos nacionais conduziram uma campanha nacional, debateram temas nacionais, e ganharam 319 dos 350 assentos (8). Muito importante, também, foi os partidos nacionais terem feito uma campanha bem intensa em áreas onde o potencial de secessão era maior e a história de um sentimento anti-sistema tinha raízes mais profundas as regióes dos bascos e dos cataláes. Embora tenham emergido dois fortes partidos regionalistas, Basco e Cataláo, os quatro partidos nacionais e seus afiliados regionais obtiveram $67,7 \%$ dos votos na Catalunha e $51,4 \%$ dos votos no País Basco (9).

Os deputados e o governo produzidos nessa eleição nacional empenharam-se em negociaçóes públicas e privadas sobre a Constituição e sobre o modo de agir quanto à questão da estaticidade. Uma Constituição consensual foi finalmente apoiada no Parlamento pelos quatro maiores partidos e o maior partido cataláo nacionalista; 258 dos $274 \mathrm{mem}$ bros votantes the deram sua aprovação. Em seguida deu-se a terceira votação nacional, a saber, um referendum sobre a Constituição, aprovada por $87,8 \%$ dos votantes em 6 de dezembro de 1978. Na Catalunha, a Constituição foi aprovada por $90,4 \%$ dos votantes. No País Basco $68,8 \%$ dos votantes aprovaram a Constituição, porém só compareceram $45,5 \%$ dos eleitores, abaixo do nível espanhol e catalăo de $67 \%$.

Fortalecido e legitimado por estas três eleiçóes, o governo nacional iniciou negociaçóes decisivas sobre a devoluçáo de poder aos governos da Catalunha e do País Basco, produzidos também no rastro das eleiçóes gerais nacionais. Cercados de intensa controvérsia, os negociadores eventualmente montaram um sistema no qual a Espanha mudaria sua estrutura de Estado, historicamente centralizada, por uma nova, des- 
centralizada, caracterizada por uma devolução, sem precedentes, de poder para os distritos eleitorais periféricos, nacionalistas. Estes acordos negociados relativos à autonomia regional (Estatutos de Autonomia) foram submetidos aos eleitores bascos e cataláes em outubro de 1979 . $O$ estatuto catalão foi aprovado por $87,9 \%$ e o estatuto basco por $90,3 \%$ daqueles que votaram nessas regióes (10). $\mathrm{O}$ maior e mais antigo partido basco nacionalista (PNV), que instigara um boicote da Constituição, ajustou-se à nova situaçáo política e recomendou a aprovação do Estatuto de Autonomia (11).

Estamos certos que, tivesse a primeira eleição na Espanha sido regional, e não universal, os incentivos para a criação de partidos nacionais e uma agenda nacional teriam sido muitíssimo reduzidos. Em consequiência, os partidos nacionais e seus afiliados receberiam menos votos (12).

Também estamos certos que, se as primeiras eleições fossem de nível regional, as questóes étnicas teriam assumido um papel muito mais substancial e divisivo na campanha eleitoral do que tiveram na realidade, e os partidos regionalistas e seus afiliados teriam sido mais extremados. Partidos regionalistas fortalecidos teriam complicado gravemente o problema da estaticidade na Espanha. As relações entre os militares e as forças democratizantes do governo central quase certamente estariam sujeitas a uma tensão mais forte. Num contexto de exacerbado conflito da estaticidade, o golpe da coalizão - desfeito pela intervençáo pessoal do Rei em 23 de fevereiro de 1982 - teria provavelmente emergido mais cedo, com maior força contra um governo dividido e menos legítimo, e teria provavelmente triunfado.

A transição democrática na Espanha certamente se iniciou em condiçóes favoráveis, porém o claro compromisso com a democratização e as eleiçóes universais fortaleceram a reivindicação de legitimidade do governo central, ajudaram a forjar vínculos entre a sociedade política e a sociedade civil e contribuíram para um novo entendimento, sancionado constitucionalmente, entre os nacionalismos periféricos da Espanha e o governo central.

Mais importante ainda, as eleiçóes nacionais reestruturaram as identidades na estaticidade, por vias que reconheceram as identidades múltiplas e a democracia na Espanha. Na nova Espanha democrática emergiram identidades muiltiplas complementares. Vemos isso mais claramente no caso da Catalunha. Os cataláes estão agora mais satisfeitos com seu estatuto de cataláes, visto terem eles, neste momento, o controle cultural e político sobre a educação, a televisão e o rádio, na maioria das 
áreas onde, no passado, era mais reprimido o nacionalismo catalăo. Os catalīes também participam como um grupo regional supranacional na Comunidade Européia que sob alguns aspectos importantes é uma comunidade de regiôes tanto quanto uma comunidade de estados. Finalmente, neste novo contexto, os cataláes, em grau bem maior do que antes, aceitam sua identidade como membros do Estado espanhol. A esmagadora percentagem de todos os catalães se orgulba de ser catalá, se orgulba de ser espanbola, e está muito a favor de pertencer a uma comunidade política européia integrada. A seqüência de eleiçóes na Espanha ajudou a constituir estas participaçóes legais e afetivas mutuamente auxiliadoras, no subEstado (cataläo), no Estado (espanbol) e no supra-Estado (Comunidade Européia), na ordem política. A tábua 1 mostra bem claramente estas múltiplas identidades complementares.

Tábua 1

IDENTIDADES NACIONAIS NA CATALUNHA

Catalăes Espanha toda

\begin{tabular}{lll}
\hline Orgulhoso de ser & $73 \%$ & $85 \%$
\end{tabular}

espanhol

$\begin{array}{lll}\text { Orgulhoso de ser } & \mathbf{8 2 \%} & \mathrm{N} / \mathrm{R}\end{array}$

catalăo

Em favor da

$83 \%$

$76 \%$

Unifiççąão da Europa

através da Comunidade

Européia

Fonte: Perguntas sobre orgulho formuladas por: Frạncisco Andrés Orizo e Alejandro Sánchez Fernández.

Pergunta sobre a Unificaçäo Européia é de "Espanhóis no 22 aniverś́rio da assinatura do tratado de adesão da Espanba à Comunidade Européia".

O País Basco apresenta um quadro político mais complexo. Nele, ainda persiste a violência separatista como rotina, mas acreditamos que a situação política como um todo melhorou com a sequiência de eleiçóes que descrevemos. Em verdade, o País Basco é um exemplo particularmente dramático de como podem as eleiçōes estruturat identidades e deslegitimar certos tipos de violência antiEstado. 
Enquanto o apoio à participação numa Europa unificada é grande, os cidadáos do País Basco são $40 \%$ menos orgulhosos de serem espanhóis do que a média nacional, e cerca de $\mathbf{3 0 \%}$ menos orgulbosos de serem espanhóis do que os catalães. Veja a tábua 2.

Tábua 2

IDENTIDADES NACIONAIS NO PAÍS BASCO

País Basco Espanha toda

\begin{tabular}{lcc}
\hline $\begin{array}{l}\text { Orgulhoso de ser } \\
\text { espanhol }\end{array}$ & $44 \%$ & $85 \%$ \\
\hline Orgulhoso de ser basco & $69 \%$ & $\mathrm{~N} / \mathrm{R}$ \\
\hline $\begin{array}{l}\text { Em favor da } \\
\begin{array}{l}\text { Unificaçáo da Europa } \\
\text { através da Comunidade } \\
\text { Européia }\end{array}\end{array}$ & $74 \%$ & $76 \%$ \\
\end{tabular}

Fonte: As mesmas da Tábua 1.

Vamos agora focalizar explicitamente a questão de como são construídas identidades por processos políticos. Entre 1977 e 1979 a mais candente questão na política espanhola era a concernente ao relacionamento dos nacionalismos periféricos com o Estado unitário espanhol. Nesse período de dois anos a percentagem da população do País Basco que declarou desejar a independência dobrou, até representar virtualmente um terço de toda a população. Partindo de uma base menor, o sentimento pró-independência triplicou na Catalunha no mesmo período. Obviamente, se estas tendências tivessem continuado por mais alguns anos, teria havido uma severa crise de estaticidade na Espanha. Entretanto, uma vez realizado o referendo sobre o Estatuto de Autonomia, e uma vez estabelecidos governos com os partidos regionalistas bascos e catalães no poder, começou a declinar o sentimento favorável à independência. Veja a figura 1.

Assassinatos, seqüestros e terrorismo por parte de grupos pró-independência no País Basco ainda continuaram após o referendo, porém sua significação política mudou dramaticamente. Em 1979, antes do referendo, somente $5 \%$ da população basca consultada em pesquisas 
PERCENTAGEM DA POPULAÇÁO A FAVOR DA INDEPENDÊNCIA NA CATALUNHA E NO PAÍS BASCO NAVARRA ANTES E DEPOIS DO REFERENDUM DE 1979 SOBRE DEVOLUÇÃO DE PODER ÀS AUTONOMIAS

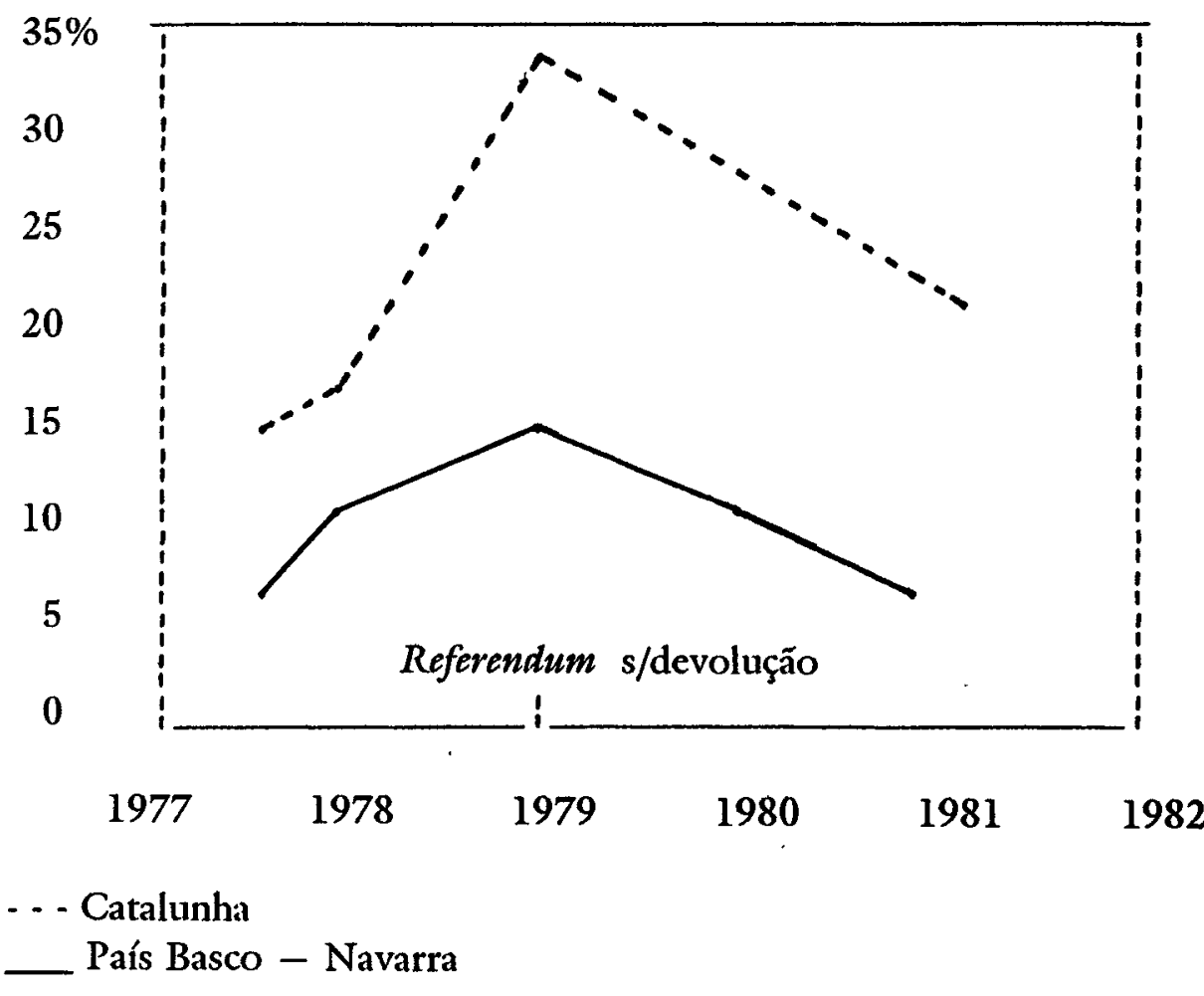

Fonte: Juan I. Linz, "Das crises de um Estado unitário a Estado e as autonomias", em Fernando Fernández Rodriguez, A Epanbr e as Autonomins.

rotulou os terroristas de "criminosos comuns", e somente $8 \%$ os chamaram de "perturbados mentais". Entretanto, três anos após o referendo, a população em geral atribuiu identidades bem mais pejorativas aos terroristas, e assim fazendo começou a marginalizá-los politicamente; agora $29 \%$ os chamaram de " criminosos", e $29 \%$ os chamaram de "perturbados mentais". E de modo mais importante, a mesma "deslegitimação de identidade" ocorreu entre aqueles que eram eleitores do maior Partido Nacionalista Basco (PNV). Em 1979 somente 6\% dos seguidores do PNV chamavam os terroristas de "criminosos" e somente 
$12 \%$ os chamavam de "perturbados mentais" (13). Em 1983 as percentagens eram $27 \%$ e $30 \%$ respectivamente. Embora continuem a ocorrer assassinatos no País Basco, eles não mais ameaçam derrubar o governo democrático. A crise de estaticidade na Espanha foi contida, graças sobretudo à escolha da sequiência eleitoral.

\section{Liberalização, eleiçóes e políticas de desintegração do Estado: a União Soviética e Iugoslávia}

Reconheça-se que, mesmo com uma condução extremamente habilidosa, o problema de estaticidade na União Soviética e na Iugoslávia teria sido bem mais difícil do que na Espanha (14). Dito isto, a orientação política de fato seguida nos dois países foi virtualmente a sequiência ótima a ser posta em prática, caso alguém quisesse desintegrar o Estado e intensificar o conflito étnico (15). O contraste com a Espanha é ilustrativo.

O primeiro ponto importante a sublinhar é que, quer na União Soviética, quer na Iugoslávia, jamais houve um compromisso claro para democratizafão como definimos o termo. Certamente que na Uniáo Soviética, a perestróica e particularmente a glasnost tinham fortes dimensóes liberalizantes. Na União Soviética a liberalização contribuiu para pressóes democratizadoras vindo de baixo, porém, nem na União Soviética nem na Iugoslávia, jamais houve compromisso das autoridades centrais de submeter o poder nacional (de toda a Uniăo) à democratização.

Em ambos os países se permitiram eleições, mas em ambos os países as mais democráticas e disputadas eleiçóes foram para os poderes regionais. O ponto fica claríssimo na Iugoslávia, onde eleiçóes nacionais competitivas simplesmente nunca se realizaram no período após a Segunda Guerra Mundial. Eleiçóes provinciais (das Repúblicas Constitutivas - N.T.) realizaram-se na Iugoslávia, no verão e outono de 1990, mas, sem surpresa, as questóes étnicas tornaram-se as de interesse predominante. A situação na União Soviética é relativamente mais complicada. As primeiras eleiçóes na Uniāo Soviética foram de fato eleiçóes nacionais para o Congresso dos Deputados do Povo em março de 1989. Entretanto, havia muitas limitações nessas eleiçóes. Elas não foram multipartidárias e assim uma sociedade política democrática náo pode se desenvolver, no sentido real. Além disto, um terço dos assentos desse Congresso de 2.250 membros (Deputados do Povo) era reservado para o Partido Comunista e suas organizaçóes afiliadas e não dependiam de ratificação popular. Ainda mais, o processo de indicaçáo permitia a muitas comissóes eleitorais locais, dominadas pelo Partido, abarrotar os 


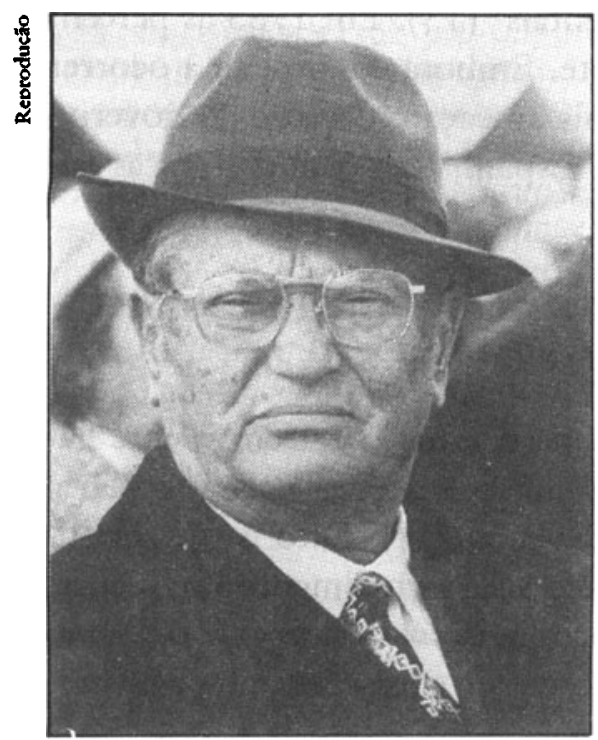

Tito, 1892-1980

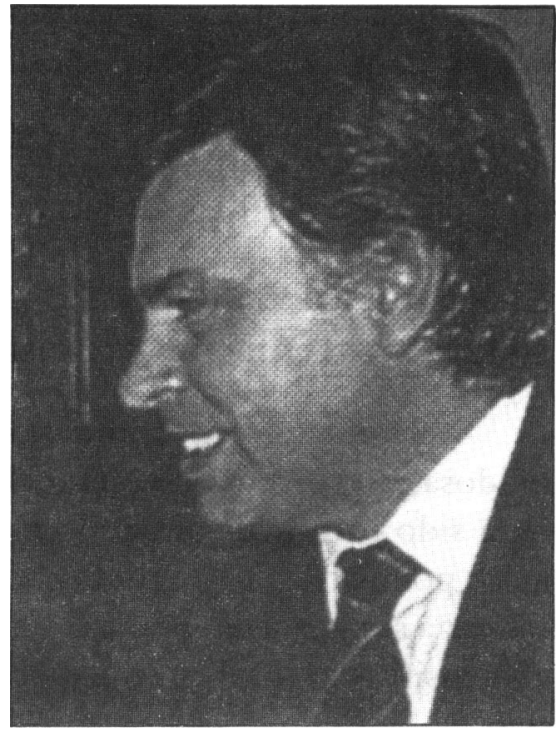

Felipe Gonzalle:

comícios com seus partidários e assim controlar o processo de indicação. Em muitos distritos, todos os candidatos saídos das comissōes eleitorais locais eram seguidores do PCUS. O que é mais, em um quarto do total, as disputas resultaram na escolha de candidatos únicos pelas comissóes eleitorais locais. Nesse contexto muitos candidatos da oposição ficaram pelo acostamento.

O altamente seletivo Congresso dos Deputados do Povo, surgido deste processo (com 2.250 membros), tornou-se o colégio eleitoral para a eleição indireta ao Soviete Supremo. Este método indireto de seleção enfraqueceu mais ainda a credibilidade eleitoral da Câmara Alta - e mais importante - produziu numerosas injustiças. Por exemplo, Boris Yeltsin obteve sua cadeira em Moscou com $89 \%$ do voto popular, mas inicialmente lhe foi negado assento no Soviete Supremo, até que um membro se ofereceu para renunciar em seu favor. Outros deputados menos proeminentes não foram tão afortunados. Assim, apesar das primeiras eleiçóes na União Soviética terem sido nacionais, a proposição permanece: as mais importantes e disputadas das eleiçóes, quer na União Soviética, quer na Iugoslávia não foram as nacionais, mas as regionais.

Cônscios das deficiências da lei eleitoral nacional, os parlamentos das Repúblicas prepararam legislação contra muitas dessas práticas que levaram ao descrédito do Parlamento federal. As regras eleitorais variaram um pouco de uma República a outra, porém, em geral, permitiram aos atores, no nível das Repúblicas, exibirem maior legitimidade, em 
comparação com os seus correspondentes no nível federal. As Repúblicas rejeitaram a garantia de assentos para o Partido Comunista e organizaçóes públicas dominadas pelo Partido. Os eleitores, na maioria das Repúblicas, a grande excessão sendo a Rússia, elegeram diretamente deputados à Câmara Alta do Parlamento. Várias injustiças ocorreram nas eleiçóes para os parlamentos das Repúblicas, sobretudo na Ásia Central, e na área dos direitos das minorias étnicas. No conjunto, porém, os de-

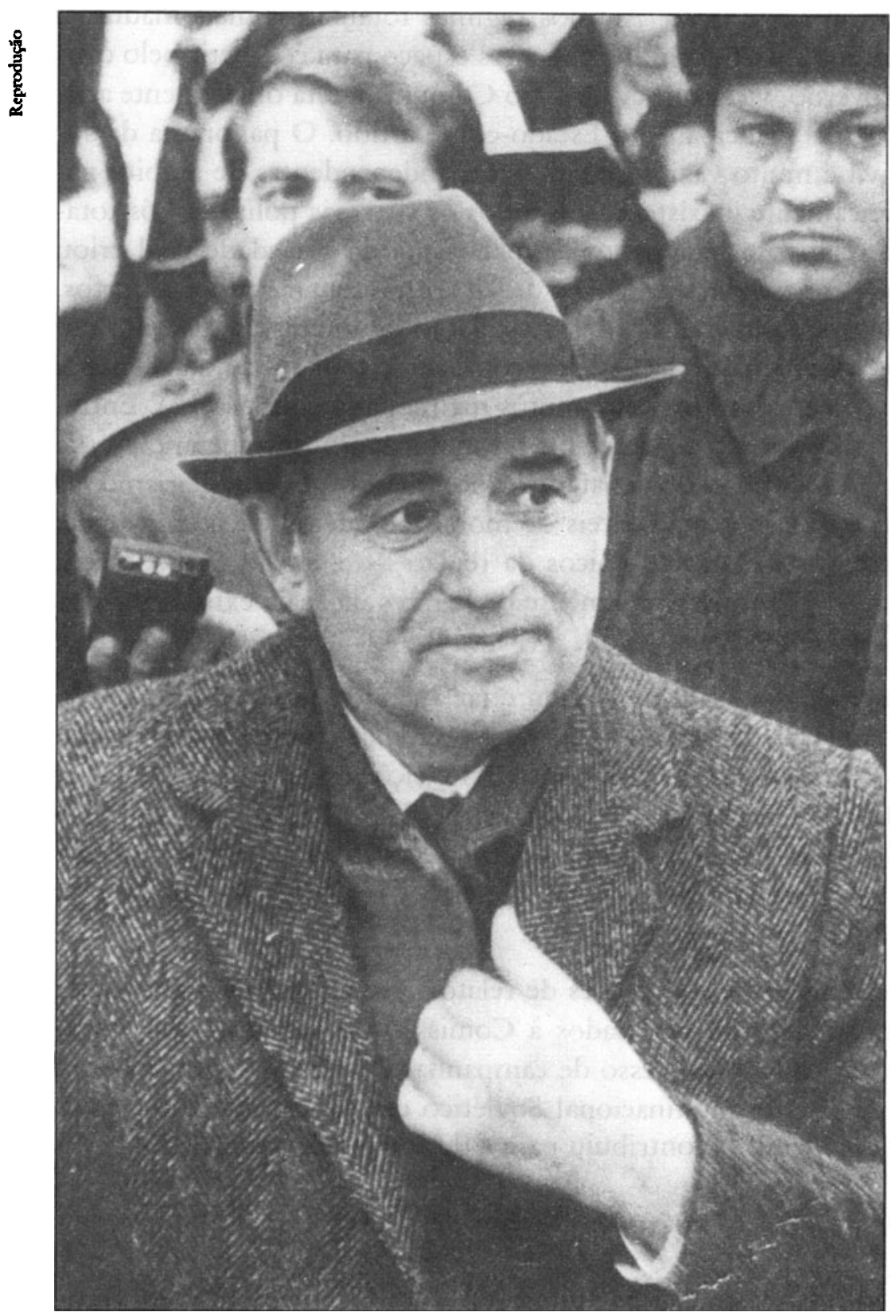

Miknil Gorbnchop 
putados dos Sovietes Supremos das Repúblicas puderam não só proclamar-se defensores dos interesses étnicos, como também puderam fazer reivindicaçōes mais vigorosas de legitimidade do que os deputados do Soviete Supremo da URSS.

Antes de analisarmos estas eleições, diremos uma palavra sobre o tipo de regime pós-totalitário (16). Um aspecto-chave de um regime totalitário é que partidos independentes preexistentes, organizaçóes trabalhistas, comcrciais e religiosas são submetidas a extensas campanhas de eliminação ou subjugação. Até nos regimes totalitários mais maduros, não se concede a partidos independentes espaço para competir pelo controle do governo, visto que ao Partido Comunista está oficialmente atribuído o "papel principal" no Estado-com-partido. O panorama da sociedade civil é muito vazio. Organizaçóes independentes de âmạito nacional praticamente inexistem. Em todos os sistemas políticos pós-totalitários, o relativo achatamento do panorama da sociedade civil criou problemas para os políticos, pois é difícil (re)presentar grupos amorfos. Mesmo depois da liberalização, a articulação de interesses baseados em riqueza, ideologia, ou relaçóes de propriedade tem sido notavelmente menor do que encontramos em muitos regimes autoritários (17). Entretanto, os políticos são especialistas na mobilização de esperanças e de reclamos. No contexto do achatado panorama do pós-totalitarismo, as esperanças e reclamos mais fáceis de mobilizar referem-se à etnicidade. Os dois estados mais multiétnicos da regiáo - a União Soviética e a Iugoslávia - foram previsivelmente os lugares da mais extremada manifestação desse fenômeno geral.

Dissemos que eleiçóes podem criar agendas, podem criar atores, podem reconstruir identidades, ajudar a legitimar e deslegitimar reivindicaçóes de obediência, e criar poder. As eleiçóes regionais na URSS e na Iugoslávia fizeram todas essas coisas. $\mathrm{Na}$ Espanha, o processo posto em marcha pelas eleições gerais nacionais reconstituiu a situação de Estado em bases ainda mais firmes. As eleições regionais na URSS e na Iugoslávia fizeram o oposto.

A série seguinte de citações de relatórios escritos pelos grupos de observadores eleitorais associados à Comissão de Helsinki capta a dimensão para a qual o processo de campanhas eleitorais regionais - no contexto do Estado multinacional Soviético que jamais se submetera a uma eleição federal - contribuiu para a desintegração do Estado.

Moldávia (Eleição: 25 de fevereiro de 1990)

" A campanha da eleição apontou para cada movimento, em com- 
petição pelo poder da República, a necessidade de desenvolver um programa de soberania, a demanda mínima na Moldávia... Se Moscou terá de lidar diretamente com o Supremo Soviete Moldávio dominado pela Frente-Popular, ou trabalhar através do Primeiro-Secretário do Partido, Lucinski, é irrelevante, pois logo se defrontará com a exigência de tornar real a soberania reclamada pela República" (18).

\section{Ucrânia (Eleição: 18 de março de 1990)}

"O Bloco Democrático de grupos de oposição formado para disputar a eleição focalizou com sucesso a campanha nas preocupaçóes dos eleitores, induzindo os candidatos do Partido Comunista, com frequiência, a agir do mesmo modo. No topo das listas dos eleitores estavam a maior autonomia política e questóes nacionais e culturais" (19).

"Crescentes demandas para uso da língua ucraniana resultaram em um importante decreto do Soviete Supremo Ucraniano estipulando que a partir de $1^{\circ}$ de janeiro 1990 , o Ucraniano será a língua oficial da República, enquanto o russo será usado na comunicação entre grupos nacionais... Sentimentos nacionalistas abafados por tanto tempo estão agora empolgando a população ucraniana" (20). " É provável que haverá ainda maior progresso para a auto-determinação ucraniana, conduzindo à independência" (21).

Geórgia (Eleiçôes: 28 de outubro de 1990)

"No dia da eleiçáo, todos os partidos na contenda, inclusive o Partido Comunista da Geórgia, advogavam a independência" (22). "Num esforço para escorar suas credenciais nacionalistas, o Partido Comunista da Geórgia exige em sua plataforma garantias da integridade territorial da Geórgia, a introdução à cidadania georgiana... Proclamando que os cidadáos da Geórgia só deviam prestar serviço militar dentro da República" (23).

O tema nacionalista da eleição exacerbou não apenas o relacionamento com o Centro, como também, o excesso nacionalista na Geórgia, e em muitas outras Repúblicas, piorou as relaçóes com os grupos minoritários dentro das Repúblicas e corroeu um componente essencial da futura democratizaçăo - plenos direitos de cidadania para todos os ha- 
bitantes, independentemente da etnia. $\mathrm{O}$ grupo observador da eleiçáo notou que na Geórgia:

"O ganhador eventual, Gamsakhurdia, fez muitas declaraçóes que alarmaram os não-georgianos. Em junho de 1990, por exemplo, ele disse que os 'casamentos mistos' são fatais para a família georgiana e a língua georgiana" (24).

"Temendo por seus direitos nacionais numa Geórgia independente, alguns grupos não-georgianos procuraram proteger-se... a República Autônoma dos Abkhas e a Região Autônoma Sul-Ossetiana declararam soberania em agosto e setembro de 1990 , respectivamente" (25).

O resultado das eleiçóes regionais na URSS e na Iugoslávia, na ausência de eleiçóes federais prévias, democráticas e livremente disputadas, contribuiu para cinco movimentos de desintegração do Estado, inter-relacionados e associados.

Primeiro: a legitimidade do governo central em todo o país ficou prejudicada virtualmente no dia seguinte às eleiçôes regionais, porque as forças nacionalistas regionais adquiriram foros de maior legitimidade democrática, através das eleiçóes (26).

Segundo: em nenhuma república da União Soviética ou da Iugoslávia surgiu das eleiçóes uma nova organização política nacional que fosse, de algum modo, contrapeso ao nacionalismo local.

Terceiro: no processo das eleiçóes, as identidades na URSS e na Iugoslávia ficaram mais unitárias, compactas, exclusivistas e contrárias à participação em uma eventual entidade democrática supranacional. $\mathrm{Na}$ Espanha, durante e depois dos processos eleitorais, as identidades se fizeram mais múltiplas, entrecruzadas, inclusivas e favoráveis à participação num Estado espanhol democrático reconstituído.

Quarto: em muitas repúblicas, tais como a Geórgia, o Azerbaijão, a Sérvia e a Croácia, a perspectiva de guerra étnica levou seus presidentes a reprimir vozes dissidentes dentro de seus grupos étnicos originários e a mostrar maior intolerância em relação aos grupos minoritários.

Quinto: a crise de estaticidade e as resultantes crises de governabilidade bloquearam a formulação e a implementação da política econômica. O cataclísmico colapso político de toda autoridade central ou coordenadora precedeu e criou a crise econômica, e não vice-versa (27).

Podemos concluir nossa argumentação das conseqüências da se- 
quiência eleitoral com as proféticas palavras de um cientista social soviético, escrevendo antes do golpe e bem antes da desintegraçáo de jure do Estado Soviético. Ele captou a que grau as eleiçóes regionais já haviam contribuído para a desintegração de facto do Estado:

"As eleiçóes locais contribuíram para o processo de mudança da retórica dos movimentos nacionalistas de ' cívicos' para 'étnicos' ... A 'guerra das leis' e o 'desfile de soberanias' seguiram-se inevitavelmente às eleiçóes locais e nas Repúblicas... A crise de poder no centro da Uniáo e o processo de ingovernabilidade aumentaram enormemente" (28).

* N. do T.: No original - stateness. Esta palavra, um neologismo das ciências sociais, quer dizer o sentido ou sentimento de estado, a essência do estado. Para não deixar o termo em inglês, optei por utilizar o também neologismo estaticidade.

** N. do T.: No original - polities.

*** N. do T.: No original all-ınion para diferenciar de (eleiçōes) parciais, regionais e provinciais e para não confundir nacional no sentido de federal, do país todo, com nacional no sentido de concernente a uma nacionalidade ou etnia. Preferi, entretanto, usar em português o termo nacional com esta advertência ao leitor.

Notas

1 Por exemplo, o estudo de maior influência quanto às transiçóes democráticas é a obra em quatro volumes editada por Guilermo O'Donnell, Phillipe C. Schmitter e Laurence Whitehead, Transifóes do poder mutoritrinio (Baltimore e Londres: Editora da Universidade Johns Hopkins, 1986), inteiramente dedicada ao Sul da Europa e América Latina, e virtualmente não contém nenhum estudo do problema de estaticidade.

2 De fato, possivelmente até um terço dos países, passados e presentes, onde a democratizaçăo constava da agenda, precisou enfrentar alguma forma de problema de estaticidade. Algumas das mais importantes categorias desse problema são: 1) "Estados divididos", onde a democracia era, ou é, mais difíil por causa de exigências de segurança, por exemplo, Taiwan e Coréia do Sul; 2) "Estados não-soberanos", onde a democracia fica impedida, porque a comunidade não controla sua soberania e a comunidade será transferida para a polis mais ampla: exemplo, Hong Kong; 3) "Estados que desejam unir-se a outros Estados e sāo impedidos de fazê-lo pelo sistema internacional", por exemplo, a Austria após a Primeira Grande Guerra, que desejava juntar-se à Alemanha; 4) Sistemas políticos (polis) "irredentistas", submetidos à violência por grupos que pretendem unir roda a sua comunidade étnica fora de seus limites existentes, em seu Estado, por exemplo, os conflitos búlgaros com o irredentismo da Macedônia, entre as guerras, e os problemas dos sudetos na Tchecoslováquia, nos anos $30 ; 5)$ "grupos étnicos minoritários ricos", que pretendem secessão, por exemplo, a guerra civil de Biafra, na Nigéria; 6) regióes étnicas mais pobres, que pretendem a secessão por acreditarem que sua economia e seus direitos vão melhorar como Estado independente, por exemplo, Bangladesh e possivelmente Eslováquia. Muitas outras categorias poderiam ser acrescentadas à lista dos problemas de estaticidade.

3 A afirmação clássica deste problema é de Robert A. Dahl: " não podemos resolver o pro- 
blema da adequada finalidade e domínio das unidades democráticas partindo da teoria democrática. Tal como o princípio da maioria, o processo democrático pressupóe uma unidade própria. Os critćrios do processo democrático pressupóem a legitimidade da mesma unidade" . Vejam dele "Democracia e seus críticos" (New Haven e Londres; Editora da Universidade de Yale, 1989), p. 207, grifo no original. Depois de uma visita à União Soviética, Dahl ampliou suas ideias sobre o tema em Democracia, poder da maioria e 0 referendo de Gorbacher, Dissent (outono, 1991), p. 491-496. Năo pensamos que a importante observação de Dahl signifique que problemas de estaticidade sejam sempre insolúveis. Antes, negociaçóes complexas, pactos, talvez realinhamentos de território e acordos associados, sāo freqüentemente necessários para que a fórmula majoritária seja aceita como obrigatória. Como argumenta Dahl, a simples insistência na fórmula majoritária per se não funciona até ser primeiro estabelecida que a unidade é apropriada.

4 A estaticidade (stateness) é uma das oito variáveis-chave que exploramos $\mathrm{em}$ um livro ainda incompleto intitulado Trnnsifóes democráticas e consolidagfro democrditicn: Europa do Leste, Europrz do Sul, Américn Latinn. Muitas das asserçōes e definiçōes deste ensaio são desenvolvidas e documentadas com maiores detalhes nesse livro. Embora neste ensaio consideremos apenas os casos históricos da Espanha, Iugoslávia e União Soviética, cremos que nosso argumento sobre sequiência eleitoral tem fortes implicaçōes teóricas e políticas para outros países heterogêneos, que ainda não iniciaram esforços para democratização. A Indonésia é caso importante nesse ponto.

5 Ricardo Garcia Damborenea, La Encruicijada Vasca (Barcelona: Editorial Argos Vergera, 1984), p. 52.

6 Sobre a "Lei para reforma política", vejam Pablo Lucas Verd, La Octnpa Ley Fundamental com prefácio de Enrique Tierno (Madrid, Tecnos, 1976) e Antonio Hernandez Gil, El Cambio Politico Español y la Constitución (Barcelona; Planeta, 1981).

7 Tanto os analistas como os ativistas devem estar atentos à diferença entre liberalizạço e democratizafr̆o. Num ambiente não-democrático, a "liberalizaçăo" pode significar $\mathrm{em}$ um misto de mudanças políticas e sociais, tais como menor censura na "mídia", espaço um tanto maior para a organização de atividades autônomas da classe operária, introdução de algumas salvaguardas legais, como baberas-corpus, libertação de prisioneiros políticos, retorno dos exilados políticos, talvez medidas para melhorar a distribuiçăo de renda, e mais importante, tolerância para a oposição política.

"Democratização implica em liberalização, mas é um conceito mais amplo, e mais especificamente político. Democratização requer contestação aberta pelo direito de ganhar controle do governo e isso, por sua vez, exige eleiçóes livres e universais, cujo resultado determinará quem governa. Empregando estas definiçóes, claro que pode haver liberalização sem democratizaçăo. Liberalizaçăo refere-se fundamentalmente à sociedade civil. Democratização envolve a sociedade civil, mas refere-se fundamentalmente à sociedade política. As transiçōes democráticas referem-se claramente à democratização e não meramente às liberalizaçóes."

8 Para a organização e desenvolvimento de partidos abrangendo o Estado todo, e a importância das eleiçóes gerais para transformaçăo das agendas desses partidos, vejam Richard Gunther, Giacomo Sani e Goldie Shabad, Espanba depois de Franco: crinfaro de um sistema partidírio competitivo (Berkeley, Editora da Universidade da Califórnia, 1988), pp. 37-177. Os resultados da eleição em 1977 encontram-se na p. 38.

9 Ibid, p. 311. 
10 Vejam, Juan J. Linz, "De la Crisis de um Estado Unitário de las Auronomias" in Fernando Fernandez Rodriguez, La España de las Autonomiras (Madrid, Instituto de Estudios de Administración Local, 1985), p. 527-672 e Juan J. Linz, Conflito en Euskadi (Madrid: Espasa Calpe, 1986). Sobre a negociaçăo do Estatuto da Autonomia Basca, vejam o relatório de dois jornalistas, Kepa Bordegari e Robert Pastor, Estatuto Vasco (San Sebastian; Ediciones Vascas, 1977), passim.

11 Alguns grupos separatistas extremados continuaram a boicotar o voto sobre autonomia, e o comparecimento global de eleitores ficou $13 \%$ inferior à media espanhola sobre a reforma constitucional; não obstante, o comparecimento eleitoral de $54 \%$ foi ainda significativo, politicamente.

12 Mesmo quando não são destacadas as questơes sobre estaticidade, os partidos regionais na Espanha tendem a obter $\mathbf{1 5 - 2 5 \%}$ mais nas eleiçōes regionais do que nas nacionais.

13 Juan J. Linz, Conflito en Euskndi, p. 698.

14 Acreditamos que a questão dos países bálticos - em virtude de complicados ressentimentos oriundos de sua antiga condiçāo de estados independentes, sua recente e forçada absorção dentro da URSS, sua riqueza comparativamente maior, e suas diferenças lingüísticas e religiosas - constituía problema insolúvel. Poderia ter sido melhor conduzida se Gorbachev declarasse reconhecer a ilegitimidade do pacto entre Hitler e Stalin, e fizesse um referendo, nos $\mathbf{5 0}$ anos desse pacto, indagando da população dos países bálticos se preferiam juntar-se voluntarimente à Uniạa Soviética. $\mathrm{Na}$ eventualidade de terem votado (como mais provável) negativamente, um acordo rápido e pacífico poderia ser conseguido, com plenos direitos de cidadania para todos.

15 O caso da seqüência eleitoral na Tchecoslováquia também requer atençáo. As eleições federais e das Repúblicas se realizaram no mesmo dia e então se torna difícil discernir o efeito direto da seqüência eleitoral. Contudo a maior parte da atividade ideológica e organizacional deu-se no nível das Repúblicas, mais do que no nível nacional. Na verdade, dos 11 partidos que obtiveram cadeiras no parlamento total, só um, o Partido Comunista Tchecoslovaco tinha representantes das duas Repúblicas. A "eleiçāo fundadora" da Tchecoslováquia deu quase nenhuma atenção ideológica ou organizacional para a formação de partidos globais.

16 As questóes sobre a implicação do tipo do regime anterior para a vin da transiçăo democrática e as trarcfrus de consolidação democrática săo tratadas em detalhe no capírulo $1^{\circ}$ do nosso livro a ser brevemente publicado: Transifíto democrática e consolidayfró democritica. Europa do Leste, Europa do Sul, America Latina.

17 Por exemplo, quando perguntaram aos europeus do Leste: "O seu país tem muitos problemas a resolver. Dos conflitos constantes da lista nesse cartão, diga, por favor, qual você considera muito importante, de alguma importância, pouco importante, ou nada importante" ; o conflito mais comumente articulado envolvia o nacionalismo, "Conflitos entre nacionalistas e o resto do pals" foram mencionados como "muito importantes" por $50 \%$ na Ucrânia, 39\% na Tchecoslováquia, $29 \%$ na Estônia, $27 \%$ na Lituânia. Em contraste problemas " entre os que têm dinheiro e os que não têm" foram mencionados como muito importantes por apenas 36, 25, 23 e 24\% dos respondentes respectivamente. Vejam Lazlo Bruszt e Janos Simon, Cultura poltricn: orientafōes políticas e econbmicas na Europa do Centro e do Leste durante a transif̧ão para a democracia, 1990-1991. The Codebook (Budapest: Fundação Erasmo, dezembro de 1991), p. 37-39. 
18 Elcifóes nos cstrudes bulticos e ns Repuiblicus Soritticns, compiladas pelo pessoal da Comissäo de Segurança e Cooperação na Europa (Washington D.C., dezembro de 1990), p. 89.

19 Ibid, p. 155.

20 Ibid, p. 119.

21 Ibid, p. 135.

22 Ibid, p. 165.

23 Ibid, p. 170.

24 Ibid, p. 169.

25 Ibid, Pp. 165/66.

26 Indicador importante na erosảo da estaticidade é o marcado declínio dos cidadáos que responderam à convocaçāo milicar da uniāo. No fim do recrutamento de 1990, o atendimento da quota na Letônia foi de 39,5\%, na Lituânia, 35,9\%, na Arménia, 22,5\%, e na Geórgia, 18,5\%. Em meados de 1991 estes números desceram para 30,8\% na Letônia, 12,4\% na Lituânia, 16,4\% na Arménia e 8,2\% na Geórgia. Mais importante, em meados de 1991 a própria Moscou tinha preenchido só metade de sua quota para esse perfodo de seis meses. Vejam Stephen Foye, "Adiamento estudantil e deficiências do poder militar", Relatorio sobre a URSS, 2 de agosto de 1991, p. 5-8.

27 O Estralo no sentido weberiano (como mostra o colapso do recrutamento) tinha desintegrado na Uniāo Soviérica, ainda antes da tentativa de golpe de agosto de 1991, um golpe cujo gatilho foi o esforço desesperado de alguns elementos de dentro das forças da Uniâo-toda do Partido, KGB, e militares para bloquear a implementaçăo do tratado $9+1$, que teria dado estado (strutus) de jure para a fragmentaçáo de fucto.

\section{Resumo}

Neste artigo os autores levantam a seguinte tese: os paises constituildos por federaçóes multiétnicas, em processo de transiçăo de autoritarismo para a democracia, têm maior probabilidade de manter sua união política se as primeiras eleiçóes e tomadas de voto, desse período transacional, forem eleiçóes de caráter nacional (geral, de toda a Uniāo) ao invts de eleiçóes regionais ou provinciais. A tese apresentada é defendida pela análise comparada dos casos de Espanha e de ex-Uniảo Soviética e Iugoslávia.

\section{Abstract}

In the above article, the authors present the following thesis: multi-ethnic federations in transition from authoritarian regimes to democracy have a much better chance of maintaining its political unity if the initial elections during such transitional period are all-union elections as opposed to regional or provincial elections. The thesis is argued thru the comparative analysis of the Spain, ex URSS and Yugoslavia cases. 
A revista Estudios Avanfrdos foi autorizada pelos autores a publicar este texto, simultaneamente com a prestigiosa revista Daedalus. O texto será um capítulo do livro que os professores A. Stepan, até recentemente professor da Escola de Ciência Política de Colúmbia, e J. Linz, da Escola de Ciência Política de Yale, estāo elaborando em conjunto. O texto foi acolhido prazerosamente nẩo só pela sua atualidade $e$ arguta originalidade, mas também pelas ligaçōes do professor A. Stepan com o IEA. Ex-professor visitante e conferencista do IEA, ele já publicou em Estudos Aprnnfrados, $(v .4, n .8)$ justamente o texto de sua conferência sobre parlamentarismo, que marcou o iń́cio do ciclo de estudos em andamento no Instituto sobre sistemas de governo.

Tradução de Luiz de Souza Dantas Forbes. O original em inglês encontra-se à disposiçảo do leitor no IEA para eventual consulta.

ESTUDOS AVANÇADOS 6(14), 1992 